\title{
River Governance and Human Security Topics in Ethiopia: An Examination of the Catchment Area Residents' Anxiety
}

\author{
Mulugeta Tesfaye Teshome ${ }^{1,}$, Sebsib Haddis Woldie ${ }^{1}$, Shimellis Hailu Dessie ${ }^{2}$ \\ ${ }^{1}$ Department of Peace and Development Studies, Wollo University, Dessie, Ethiopia \\ ${ }^{2}$ Department of Political Science and International Relations, Wollo University, Dessie, Ethiopia
}

Email address:

mulugetaabateee@gmail.com (M. T. Teshome), hadissebsib@gmail.com (S. H. Woldie), shimellishailu@yahoo.com (S. H. Dessie)

${ }^{*}$ Corresponding author

\section{To cite this article:}

Mulugeta Tesfaye Teshome, Sebsib Haddis Woldie, Shimellis Hailu Dessie. River Governance and Human Security Topics in Ethiopia: An Examination of the Catchment Area Residents' Anxiety. Advances in Sciences and Humanities. Vol. 5, No. 4, 2019, pp. 98-104. doi: 10.11648/j.ash.20190504.12

Received: July 15, 2019; Accepted: August 7, 2019; Published: August 29, 2019

\begin{abstract}
This paper discussed the human security issue induced from poor river governance in Ethiopia by selecting Borkena River as a show case. To address the problem at hand qualitative Case study research design is employed and primary data were collected through in-depth interview and field observation. Though rivers in Ethiopia in general and Borkena River in particular are sources of livelihood of many people in Ethiopia. Rivers in the country are exposed to different kinds of stressors like environmental pollution, riverside settlement, envision of foreign water weeds, and environmental degradation. This research identified that flood, conflict, pollution and depletion, are the major human securithy threats that affect the local people's normal life. Based on the finding, research implied that there is an urge to clean and treat the river water to make ready for use. Simultaneously the government agency need to control pervasive pollutants and should give compensation for those who lost their livelihood due to pollution. Environmental Protection works are imperative to maximize the rivers utilization and sustainability of the resident's life.
\end{abstract}

Keywords: Borkena River, Human Security, River Governance, Security Threats

\section{Introduction}

Governance is a complex concept and thus there is confusion about governance in general and water governance in particular. Along the conceptual obscurity of governance, what constitute good governance and in turn water governance is in question. De Stefano defined water governance as "the manner in which authority is acquired and exercised on behalf of the public in developing, utilizing and protecting a nation's water resources" [1]. Global river governance is now associated with 'human security' because water is linked with food security, energy security and environmental security. In this regard, a technology oriented solution come to the scene to solve problem of 'global water crisis' and to save life. Nevertheless, technology alone never solved the problem. Rather water scarcity remains unsolved problem of the global community. At worst it is predicated that scarcity of water coupled with population growth, climate change and land degradation may leads to violent conflict and consequent human security threats.

River governance in Developing countries are not in line with these features and mal governance often induced human security threats to the local people where they depend on it. In the following pages the paper highlights key concepts and relation between poor river governance and human security threats.

\subsection{Human Security, Environmental Change and River Depletion Nexus}

Though there is disagreements in defining security, scholars adopt a working definition for the term. It is defined as the alleviation of threats to acquired values, interest and goals. If threats left unchecked, they threaten the survival of a particular referent object in the near future. Security is also best described and understood as 'survival-plus,' "the "plus" being some freedom from life-determining threats [2]. 
Security means the absence of threats, emancipation from those human physical constrains that stop them from carrying out what they would freely choose to do [3].

In resent works security is defined in narrower and broader senses. Security in an "extended" sense takes many forms. In the most commonly known concepts, security is horizontally extended, from military to political, economic, social, and environmental. It is commonly termed as "human security". Human security in its broadest sense embraces far more than the absence of violent conflict. It encompasses human rights, good governance, access to education and health care [4].

It is to means protecting fundamental freedoms - freedoms that are the essence of life. It means protecting people from critical (severe) and pervasive (widespread) threats and situations. It means using processes that build on people's strengths and aspirations. It means creating political, social, environmental, economic, military and cultural systems that together give people the building blocks of survival, livelihood and dignity [2].

Human security activists advocate ensuring each individual's choice to fulfill his or her own potential. Human security places the individual at the center of analyses.

Indeed scholars like Schwatz support the strict demarcation between what they consider "low" (economic and environmental) human security and "high" (military) human security agendas [5]. But, opponents of the redefinition of security focused solely on the military dimensions that exposed the world for escalation of nonmilitary threats. For example population growth, demographic issues, environmental pressures, pollution, and resource scarcity produce economic decline and deteriorating human health conditions. Proponents of redefining security stress that in an increasing social and economic interdependence misguided the world to consider military threats as the supreme security concern [4]. In most part of the world economic as well as environmental issues, need to be addressed via the redefinition of security.

These implied that environmental security is concerned with the maintenance of the local and the planetary biosphere as the essential support system on which all other human enterprises depend [6]. The real sources of insecurity encompass environmental depletion and unsustainable development. Environmental stress/depletion can be an important factor of the web of causality associated with most conflict and can in some cases be catalytic. Environmental depletion induced poverty, injustice, environmental degradation and conflict interact in complex and potent ways which pose pervasive threat on human security.

Few threats to peace and survival of the human community are as equal as irreversible degradation of the biosphere on which human life depends. The recent human misery, migration and violent conflict are suggesting that the environment would be the 'national-security issue of the early twenty-first century. The scale of the attention on the 'security - climate change debate' in recent years is visible in various policy reports. In most parts of the world, the nexus is controversial. Many publications [7]; [8] and [5] from the project have produced largely abstract conceptions of the environment-conflict nexus.

Homer-Dixon argued that the commonly used "environmental change" refers to a human-induced decline in the quantity or quality of a renewable resource much faster than natural processes renew it [8]. He believes that environmental decay induced scarcity and unequal resource distribution on the one hand and social conflict on the other hands which negatively affect sustainability of resource utilization. Homer-Dixon concluded that armed conflicts would arise with because of environmental change and natural resource scarcity.

Environmental change induced conflict seems as micro conflict which can be locally and peacefully resolved by government regulation or negotiations. However, environmental degradation could be a background or triggering factor in macro ethnic or political conflicts. In the same way Goldstone admitted that environmental change were truly a major and pervasive cause of violent conflicts when they are mixed with other sociopolitical factors [8]. It is important to avoid linear causal explanations when assessing whether natural resource and population movements may lead to an increase in violent conflict. Parker argued that [environmental] change would more likely serve as a threat multiplier that exacerbates pre-existing issues, such as weak rule of law or social and economic injustice [9]. CHS consider threats of human security as mutually reinforced issues. The explanation of "domino effect" cool down the debate on whether "environmental degradation resulted in violent conflict or not".

threats to human security are mutually reinforcing and interconnected in two ways. First, they are interlinked in a domino effect in the sense that each threat feeds on the other. For example, violent conflicts can lead to deprivation and poverty, which in turn could lead to resource depletion, infectious diseases, education deficits, etc. Second, threats within a given country or area can spread into a wider region and have negative externalities for regional and international security [2].

Therefore, environmental degradation, scarcity, flood, drought and conflict are mutually reinforcing threats for human security in developing countries. This is the result of a number of interconnected factors. Most notable one is the way natural resource exploitation is problematic. It is not by technological advancement. This in turn could affect the use of other resources and could threaten sustainable production itself. Especially in the highlands forest clearance and charcoal production is very common. Agricultural land expansion follows the forest clearance. In these areas there is the highest erosion risk due to dissected topography and heavy rainfall. Connected to soil erosion, there are risks from siltation and altered hydrological regimes as deforestation occur. These would affect both the hydroelectric power generation and the use of the rivers for irrigation [10]. Finally it threatened the life of the local people's. The pressure induced migration and conflict for resource. These is straightforward connection between environmental 
degradation and human security threats.

River depletion is one of the rampant environmental problem in the contemporary world and unquly in developing countries. Rivers are important components of environment that many ecosystem depends on it. In addition rivers in the world are a critical source of clean water supply unlike bulk of water in the world's ocean. The earth's major source of fresh water are rivers and they are rapidly depleted by human mismanagement. Multiple stressors, such as agricultural runoff, solid and liquid wastes' pollution and alien water weeds species, threaten rivers that serve of the world's population as a source of fresh water. These stressors endanger the biodiversity of the world's river habitats putting thousands of aquatic wildlife species at risk. Such depletions threatened the rivers and posed an economic burden and human security threats which often out of reach for developing nations. This paper give a flashpoint on the human security threats caused by river depletion at the study area. With this approach the researchers assume that the protection of rivers means the promotion of human security in different respects and the opposite is true for posing threat on the wellbeing of human life.

In addition to local water governance problems, global climate change syndromes like unstable water volume, air pollution and global warming are a "threat multiplier", exacerbating existing stresses and creating volatile situations. The insecurity related to river mal governance is most likely fueled by widespread poverty, high unemployment, forced immigration, instability, hunger and general social discontent [3]. Ultimately, the ability of the government and communities to address and adapt to these changes depends on their knowledge and understanding of the complexities [3].

\subsection{Conceptual Framework}

Our conceptual Framework, Framework of Multilayered water governance and Human Security implications' basic assumption is that water governance is multilayered and complex. First, in terms of actors, water governance involves multiple actors' water users with un-negotiable interest at local, national, regional and international levels. Second, issues in water sector are diverse which includes water as human right issues, water scarcity, food security, and equity, gender, identity, competition and conflict- human security issues. Finally, institutions with regard to water governance are diverse which includes governmental institutions at various levels, private institutions, water user's association and NGOs. Mal river governance specifically threatened the local peoples' lives in different extent.

Thus, water governance and related human security issues are multilayered complex issues which can be understood by employing multilayered framework. In view of that, this study employed this framework to properly examine the trends of water Governance and human security challenges in the upper and lower catchment of Borkena, found in Eastern Amhara Region which is a major tributary of Awash River.

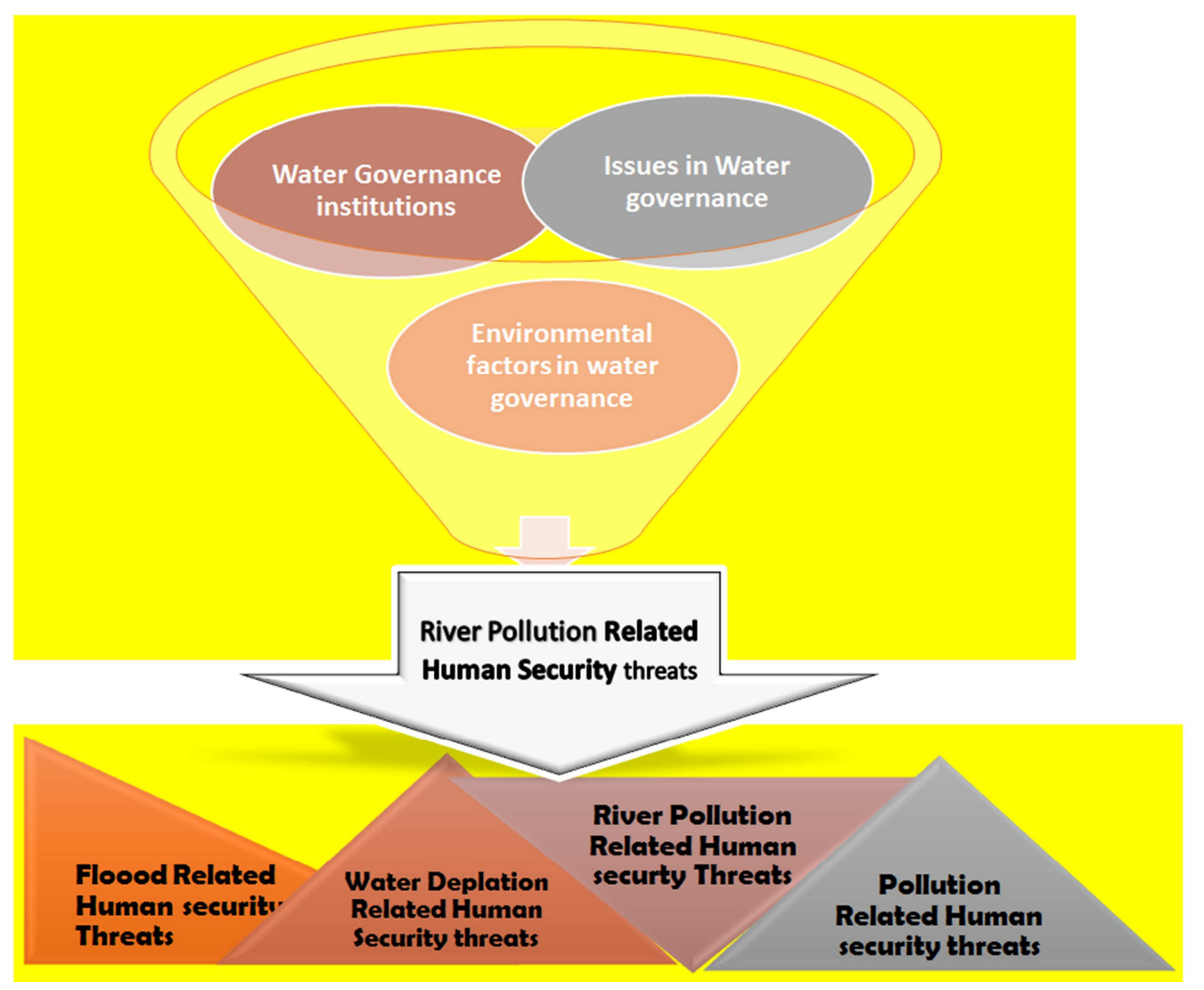

Source: adopted from IRMA, 2004 in [11]

Figure 1. Framework of Multilayered Water Governance and Human Security Implications. 
Since rivers in Ethiopia are the source of Drink Water, Construction materials (sand, Stone and forest product), grazing field, place of recreation, sanitation, water source for irrigation and served as public space. Many lives depend on rivers by extracting natural resources as their source of livelihood. Therefore depleting river means threatening the life and livelihood of residents in the catchment area. Rivers in Ethiopia gets less attention and considered as common good of the local people. Such distorted perception on the ownership of river causes competition in exploiting the river unsustainably that pose threat on local people's life. By taking Borkena River as a show case the researchers investigate the security threats that affect the local people's life due to the river's exhaustion.

\section{Materials and Methods}

This study is exploratory in its purpose and case study in its design. The case study is one type of qualitative research design that facilitates exploration of a phenomenon within its context using a variety of data sources. The study design is employed to explore the human security implications of Borkena River governance through variety of lenses. The researchers mainly used primary data because it gives firsthand information and the topic can be deeply investigated by primary source. To generate sufficient information about the topic, data were collected through indepth interviews and observation. Qualitative data analyzed by involving continual reflection about the data and writing observation memos throughout the study. The researchers makes detailed description of the setting, followed by coding, transcribing and organizing the response thematically.

\section{Result and Discussion}

Human security is inter-disciplinary concept that displays the characteristics of people-centeredness, multi-sectarian, comprehensive, context specific and prevention oriented [12]. The threat range includes economic threats, food related threats, health related threats, environmental threats, personal threats, community threats, and political security [12]. In many parts of the world, river pollution are posing human security threat in many ways [13]. People in the catchment area faced security threats induced from Borkena River pollution. Under this section human security issue related to Borkena River pollution is going to be presented. This paper explain the vulnerability of the local people for summer time flooding, conflict over water resource, scarcity of water and pollution induced water-borne diseases. River pollution poses the most immediate and acute threat to human security at its different forms.

\subsection{Conflict Related Human Security Threat}

The major human security issue in river water is conflict or disagreement between upper riparian and lower riparian over sustainable water supply. As the collected data informed, the lower and middle riparian of Borkena River inter into disagreement for securing statuesque of using the river. For example in the most upper of Borkena River, farmers faced the threat of conflict for sustainable water supply for their small scale irrigation and household consumption. The emerging new demands in changing the historic utilization of Borkena River in this site threathened the historic traditional irrigated agricultural farmers. In this segment of the river catchment, the previous trend is using traditional irrigation for fruit and vegetable production. Unlike this customary river water use, the new interests emerged what we call the "the New Water Use Trend"- water reservoir construction, expanding irrigation site for rural youths employment by the support of local government in the form of irrigation, and increased amount of water consumption for historic water users due to price rise in agricultural products which motives farmers to produce more. The customary water use and the new demands are in competition and feel threatened by each other. According to our respondents in the most upper basin of Borkena River there is tension between these actors.

There are similar tensions in lower and middle basin due to increased demand for irrigation along river water. Unlike the Most upper basin, the lower basin residents inter into disagreement on the share of the water for irrigation. Most of our respondents exclaim the winter water amount is decreasing for a number of reasons like motor pump, loss of springs and swamp, rainfall decline and increased water demand. In addition People in the middle and lower valley particularly Boru Ssilasie, Nigo Giorgis/Kombolch and Tay Ager inter into conflict with their immediate upper Pollutant actors. According to respondents in this segment of the river catchment area, the river water is polluted and damage the the health of their crops, fruits and pets. Particularly these kind of conflict arises in areas where Borkena River became the sole source of water. Boru silasie with Boru town; Kombolcha with Dessie and; Taye Ager with Kombolcha municipality are few of them.

\subsection{Flood Related Human Security Threats}

As discussed above the depletion of the river canal due to unmanaged extraction of stone and sands will led to unexpected flood diversion and risk of flooding to the settlement areas, irrigation site, and Business organizations. Flood is an imminent and real threats that were damaging farmlands and forest areas in the upper and middle segment of Borkena River. In the upper segment the stone crusher machines faced flooding risks. The upper valley of Borkena river is left without any kind of environmental rehabilitation. Tracks collecting sand and stone across the river were observed that harm the biodiversity at large, and also worsening the river side erosions to be deepen and broaden in the catchment areas. In addition the solid waste accumulation will block the canal in the future. The researchers observed that the river canal was blocked by the deposited soil and plastic material in different places. 


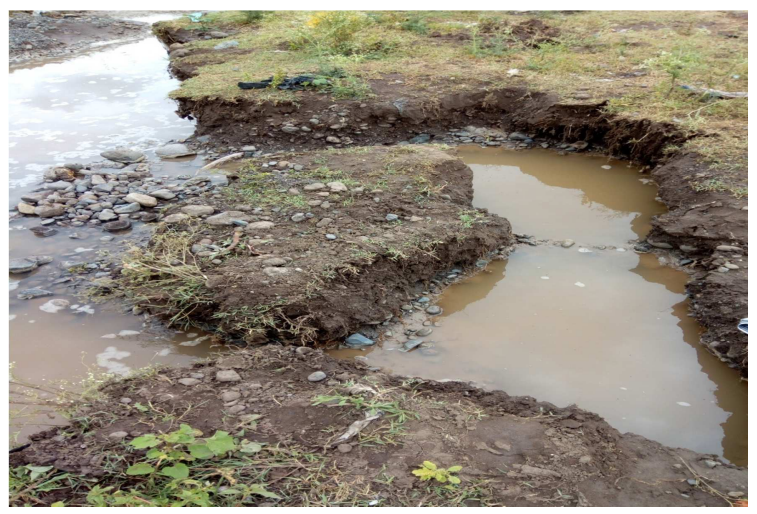

Source: Photo Taken at Kombolcha (Field observation, 2019)

Figure 2. Flood Related Challenges in the Borkena River (Kombolcha Town).

In the middle and lower segments (Kombolcha to senbetie) the river damaged irrigation sites, Stone Crashers, grazing stripes and water springs. Due to unmanaged extraction of granite stone in the river the researchers observe the machine stop working. Surprisingly despite its multiple purposes, there is no river basin flooding and land slide protection terracing except in some sites. The buffer zone of the river was exposed to illegal settlement and small scale irrigation. In Kutaber, Boru, Dessie, and Kombolcha the researchers observed river side settlements. Particularly the Arera propoor housing in the geologically unstable site and Kombolcha river side shanty houses are threatening the lives of the local people. These negligent human actions at the river will cost human life due to excess summer flood.

\subsection{Water Depletion and Fresh Water Scarcity Related Human Security Threats}

Ill constructed water tanks in the name of enhancing ground water lead fresh water scarcity. According to the respondent from Water and energy Offices, water tankers are not properly constructed and cause for loosing swamps and springs. Due to these, rural communities complaining for lack of access to fresh water.

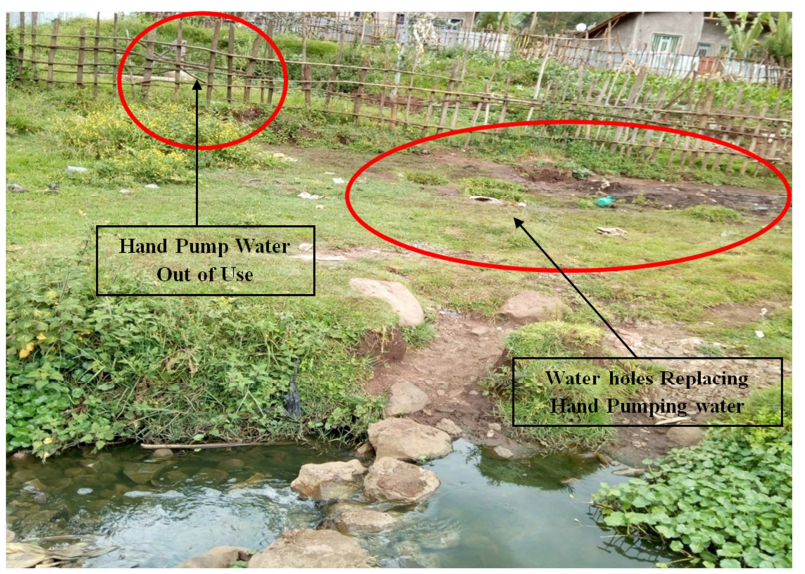

Figure 3. Handy Pumped Water affected by river pollution (Dessie Town, Menafesha Sub-city).

Source: Photo taken at Dessie Town, Menafesha Sub-city (Field observation, 2019)
Alien water weed widely seen in the upper catchment area of Borkena (Kutaber to Dessie) and observed at the lower catchment area poison and evaporate the river water rapidly. Water loss happened due to rainfall decline, sediment, and direct disposal of construction, pollution, erosion and Eucalyptus tree proliferation. Eucalyptus tree is widely planted in the upper valley which mostly affects river volume, spring water amount. As the respondent explained a number of swampy areas are dried and many springs disappeared after this tree proliferate in the area. In Dessie and Kombolcha the river water is almost no more in use for drink and bath. According to the respondents in Tayager, Lower segent of Kombolcha, the water is polluted and they are suffering from shortage of fresh/clean water.

\subsection{Pollution Related Human Security Threats}

Almost all Kutaber town solid waste dumped to Borkena river where there is also illegal housing adjacent to Borkena River violating the 50 meters river buffer zone that release their solid and liquid wastes in to the river canal through all segments of the river. All villages and towns in the Borkena River catchment areas dumped both solid and liquid wastes in to the river canal and by the river side. These pollutants damaged grassing lands, water quality, and farmlands which are economic basis for the local people in the catchment. Due to the pollution of the grassing land as the informant said some domestic animals swallow plastic with grass and affect the health and productivity of the animals. One of the informants told the researchers that his cattle dead due to swallowing plastic with grass. It also affects the production of fruits and vegetables. The farmers complained as their production decrease from time to time due to the pollution of Borkena River. The other informant in Dessie town around Wollo University explained that the local farmer's sheep died by interring into the polluted river that the farmers presume it is due to the chemical content of the river. As the farmer explained cattle that contact with the river water lose their hair and acquire skin death. As the respondents explained the waste affect children's health (skin itch, common cold, Influenza, asthma, insects bite, and worms). Unlike the local people's compliant, travelers let their animals drink that water. Local People used for mud preparation which would be used for traditional houses construction.

Indeed the University tried to install pipe line from the septic tank to the outskirts of the household's compound. But, the pipeline is not functioning. Even it causes land slide. The local people complain that the University fails to solve the problem. For them the municipal did the same.

The local people believe that the University and the Municipal did systematic eviction. Due to the unwise waste management of the University, Borkena River depleted and many spring waters are lost. Even hand pumped water institutions were built to the river side and some of the hand used pumps are prohibited for use due to suspect of underground water pollution. The local people faced grazing land and water scarcity. 


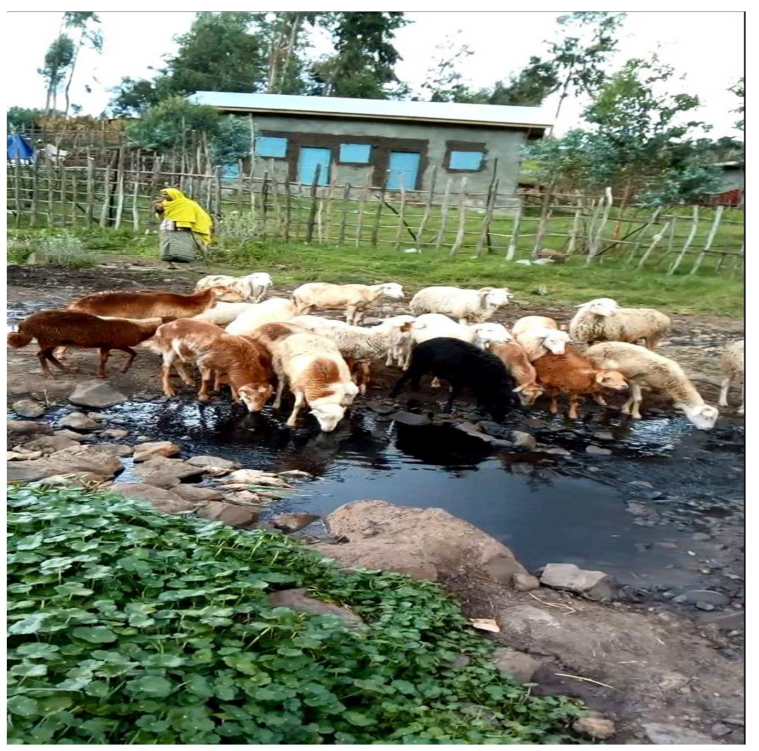

Figure 4. Domestic animals consuming the Polluted Borkena River water.

Source: Photo taken at Dessie Town, Menafesha Sub-city (Field observation, 2019)

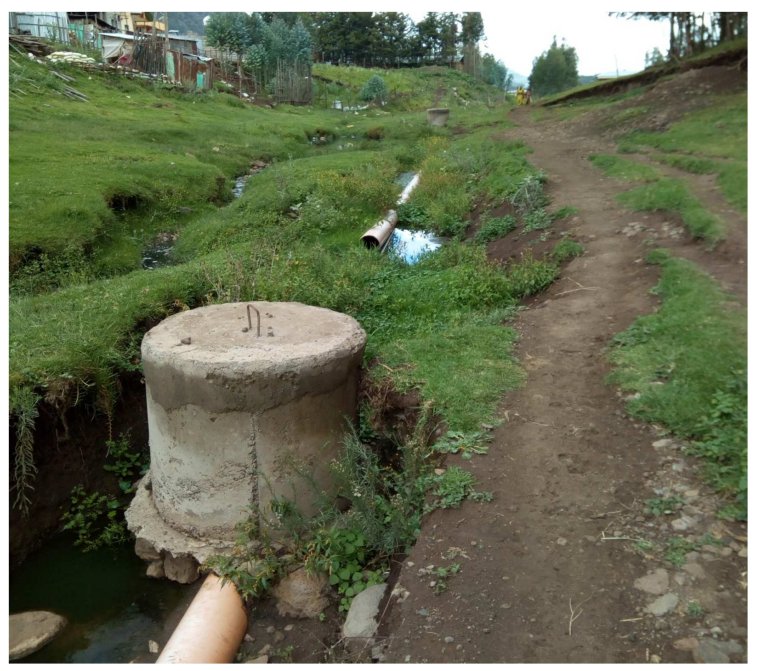

Figure 5. Broken sewerage pipeline causes land slide.

Source: Photo taken at Dessie Town, Menafesha Sub-city (Field observation, 2019).

Poultry farming and water tank of Kombolcha town are found in the near distance at the Borkena River Side. Poultry in Dessie is also by the river sides. The Dessie city water and sewerage authority expert argued that the waste polluting Borkena River has direct impact in polluting underground water including Kombolcha town water tank. The liquid wastes are disposed to Tita at the farmland of the farmers. The treatment plant of Dessie town which costs 23 Million birr ill functioning. The design is not appropriate for the town like Dessie which has shallow underground water.

As mentioned in the above paragraph, the local people said that the government does not respond for this problems. According to the respondents no government or nongovernmental actor can listen to their compliant. Around the Kera area there are Pro-poor housings and all residents built toilet to the jungle and by the side of flood canals. The toilets are constructed on unstable land and frequently face land slide which could pollute the surrounding water way. In addition residents express their worry that the liquid waste released from the Kera can exacerbate the existing land slide.

As compared to the upper segments of Borkena River in Kombolcha town, the lower segment is highly polluted. Dangerous solid wastes are found in the river canal like Garage wastes, hospital wastes and expired medical tablets. Given that the community used the river water for home consumption in the lower basin, it would be life threatening for the mentioned community. As explained above health institutions have no proper mechanism to dispose their solid and liquid wastes which spit it in to Borkena River.

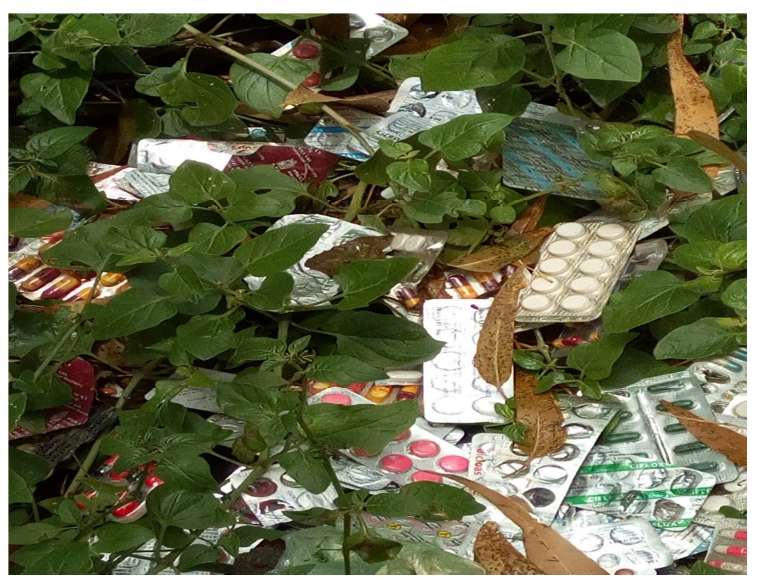

Source: Photo taken at Kombolcha Town (Field observation, 2019)

Figure 6. Drugs Dumped to Borkena river bank.

The solid wastes which the river carries through sediment at the lower bank of the river which is called the lower bridge deposed the solid to the surface of the bridge that might block the water flow. In the near side of the bridge the researchers observed that youths are bathing, cows drinking the water and the town solid wastes deposition and garage remnants solid wastes are deposited their which harm the river water.

\section{Conclusion and Recommendation}

The condition of water governance affect the status of human security of the local people in Borkena River catchment area. Since governance is a multilayered institutional interplay, the process is a complicated phenomenon. Despite this fact river governance in developing countries is not in line with the basic features of modern river governance. According to the finding of the research, Borkena River is important source of wealth that a number of lives depends on it. Borkena River is owned by all and protected by no one. Borkena River is exploited and rapidly depleted which face the fate of "tragedy of commons". In addition there are multiple stressor such as agricultural chemicals run off, solid and liquid wastes, alien water weeds, and River side settlements. 
Such stressors poses human security threats against the local people's lives. As the data implied flood related security threats, water depletion security threats, pollution related security threats and conflict related human security threats are the major hindrance that deter and disturb the normal lives of the local people who depends on the river.

Conflict over the river's resource is becoming the disturbing phenomenon that threaten the peaceful coexistence of the residents. People in the catchment area go for conflict due to sharing of water for small scale irrigation, extraction of resources and waste disposal. The scale and the level of conflict increased as the values of the river's resource price increased and become scarce because of both depletion and problem of allocation.

Unmanaged extraction of the resource hastened by rain fall variation exposed the river side residents for flood related human security threats. In some areas the river canal is blocked by construction excavation and solid waste dumping. Worst of all the scale of construction by the river side is increasing. A lot of shanty houses are constructed illegally which are vulnerable for summer time flood. Such a negligence will costs many lives in the future. During the data collection researchers observed the eroded irrigation sites due to diversion of the river flood. It damage stone crasher machine, water institution and public spaces.

In addition the river water is alarmingly depleted because of pollution, alien water weeds, rail way construction, rainfall anomalies, sediment accumulation and solid waste dumping. Borkena River especially in its urban segments is the dumping site of solid and liquid wastes. Such a waste ranging from excavated soil to hospital wastes. Dangerous chemicals released from factories and joined the river water with ran off. The lower catchment residents suffer from such kind of security threats.

The research implied that there is an urge to clean and treat the river water to make ready for use since it is a sole source of water supply to the lower catchment area people. It would save many lives that depend on the Borkena River water. Simultaneously the government agency need to control pervasive pollutants and should give compensation for those who lost their livelihood due to pollution. Environmental Protection works are imperative to maximize the rivers utilization and sustainability of the resident's life.

\section{References}

[1] De Stefanoa et al (2014) Water governance benchmarking: concepts and approach framework as applied to Middle East and North Africa countries, Water Policy 16 (2014) 11211139.
[2] Commission for Human Security Unit (2003). Human Security in Theory and Practice: An Overview of the Human Security Concept. United Nations Trust Fund for Human Security. http://www.un.org/humansecurity/sites/www.un.org.humansecu rity/files.

[3] Aduloju, A. and Omowunmi O. (2014). "Human Security and Developmental Crisis in the Contemporary West Africa." Pratt Journal of Human Security Volume $10 \mid$ Issue 1 Pages 46-58. DOI: 10. 12924/johs2014. 10010046.

[4] Japan International Cooperation Agency (JICA) (2010). "Human Security" Approach Features and Case Studies. Features and Case Studies, Tokyo, Japan. Retrieved from: http://www.jica.go.jp/english.

[5] Schwartz, D. (1999). Environmental Conditions, resource and Conflict: An Introductory Overview and Data Collection. UNEP Environmental Information (pp. 1-46). Nirobi: Division of Environmental Information, Assessment \& Early Warning (DEIA\&EW) United Nations Environment Programme (UNEP).

[6] Buzan (1987). An Introduction to Strategic Studies: Military Technology and International Relations. London: Macmillan in association with the International Institute of Strategic Studies.

[7] Goldestone, J. (2002). "Population and Security: How Demographic Change Can Lead". International Affairs, vol. 56, no. 1, The Trustees of Columbia University, New York.

[8] Homer-Dixon, T. (1994). "Environmental Scarcity and Violent conflict: Evidence from Cases". Peace and Conflict Studies Program of Toronto, International Security, Vol. 19 (I), and Pp. 5-40.

[9] Parker, M. (2013). "Backdraft: The Conflict Potential of Climate Change Adaptation and Mitigation". Environmental Change and Security Program Report, Vol/14/issue/02.

[10] Wood, B. E. (2013). What is a social inquiry? Crafting questions that lead to deeper knowledge about society and citizenship participation. SET: Research information for teachers, 2013 (3), 20-28.

[11] Ballabh (2008). Governance of Water: Institutional Alternatives and Political Economy, SAGE Publications, India.

[12] Human Security Unite (HSU) (2009). Human Security in Theory and Practice. An Overview of the Human Security Concept and theUnited Nations Trust Fund for Human SecurityHuman Security Unit. Accessed from www. un. org/humansecurity.

[13] Large, J. and Sisk, T. (2006). Democracy, Conflict and Human Security: Pursuing Peace in the 21st Century. International Institute for Democracy and Electoral Assistance, Stockholm. 